\title{
Weeds in Gwalior and nearby regions and their medicinal properties: A case study
}

\author{
Sapna Kondalkar ${ }^{1 *}$, Avinash Kondalkar², Vijay Kumar ${ }^{1}$, Anupam K Mangal ${ }^{3}$, Om Prakash ${ }^{1}$ \\ ${ }^{1}$ Regional Ayurveda Research Institute for Drug Development, Gwalior, Madhya Pradesh, India, ${ }^{2}$ Sun Institute of Pharmaceutical Education and Research, Lahar, \\ Madhya Pradesh, India, ${ }^{3}$ Central Council for Research in Ayurvedic Sciences, New Delhi, India
}

\section{ARTICLE INFO}

Article history:

Received on: June 26, 2018

Accepted on: August 29, 2018

Available online: March 15, 2019

\section{Key words:}

Climate change,

Pharmacological action,

Phytoconstituents,

Weeds.

\begin{abstract}
Weeds are normally unwanted plants at wrong place. From the perspective of crop protection, they may have a negative effect on cultivated crop, and thus, their effective management is necessary. From a medicinal perspective, they may be useful in disease management due to their secondary metabolites, affordability, inexpensiveness, accessibility, and use by native peoples. The present study reviews the literature available on weeds of Madhya Pradesh, India (Gwalior and nearby region), with their occurrence in changing environment and reported uses in disease management. A comprehensive literature search was done to get the thorough information on the versatile weeds of Gwalior and nearby regions. Amaranthaceae, Asclepiadaceae, Euphorbiaceae, and Asteraceae are found to be the most prevalent families with plants to treat Prameha, Sandhi sula, Udara sula, and Tvaka roga. The review summarizes the weed plants available in the area under the study with their reported uses, which could be further validated scientifically and could be important from the ethnopharmacological and socioeconomic perspective. This could be the best use of a waste and promote utilization of available resources for the management and treatment of prevalent diseases in the specific area.
\end{abstract}

\section{INTRODUCTION}

Weed science is the management of vegetation, while weeds are the plants out of place or the plants which grow by their own without human efforts and compete with cultivated crops for nutrients and natural resources. Weeds dominate for vegetation so affect the crop negatively. However, the word weed sounds negative, and many plants known as weeds may be beneficial. Many of them are edible and can be used in food and as herbals [1].

In the state of Madhya Pradesh, Gwalior is located at $26.22^{\circ}$ north latitude and $78.18^{\circ}$ east longitude and approximately $197 \mathrm{~m}$ above from sea level. Temperature in summer reaches up to $47^{\circ} \mathrm{C}$ while falls up to $3^{\circ} \mathrm{C}$ in winter with average rainfall in monsoon only [Figure 1] [2].

Temperature influences many physiological processes such as photosynthesis in plants, absorption of water and nutrients, respiration, and enzymatic activities, which controls and affects germination, inflorescence, viability of pollens, fruit setting, maturation rate, yield, abscission, quality of crop, harvesting period, and shelf life. Plants vary in their temperature requirements, and the variation in

\section{*Corresponding Author:}

Sapna Avinash Kondalkar, Regional Ayurveda Research

Institute for Drug Development, Gwalior - 474 009,

Madhya Pradesh, India. Phone: +91-9926999761.

E-mail: sapna.soni@rediffmail.com temperature affects photosynthesis by increased rates of chemical reactions [3]. It is a common hypothesis that temperate regions have vast phytodiversity [4].

Weeds have greater diversity than plants, and the change in resources due to environmental impact affects their growth and reproductive response [5]. To persist in changing climatic conditions, weeds have to respond these environmental changes and have to choose to migrate to a favorable climate, to acclimatize these changes in climatic conditions, or to adopt these changes, which may result with the evolution of new characteristics.

This type of biological adaptation of weeds, driven by natural selection, results in trait shifts. At the population level, it is apparent but is brought by morphological, physiological, and genetic processes at the individual plant level $[6,7]$.

Climatic changes also affect the secondary metabolite profile of plants, and the same plant species growing under different environmental conditions show significant differences in the production and accumulation of the primary and secondary metabolites [8]. This is an attempt to study the weed plants in nearby region with respect to their growth in changing climate and their medicinal importance [Table 1].

\section{MATERIALS AND METHODS}

A comprehensive literature search was done to get the thorough information on the versatile weeds of Gwalior and nearby regions. 
Table 1: List of plants grows as the weed and used as medicine in Gwalior and nearby regions. [9]

\begin{tabular}{|c|c|c|c|c|}
\hline Common name & Botanical name & Family & Medicinal use & Distribution \\
\hline Changeri & Oxalis corniculata $\mathrm{L}$. & Oxalidaceae & Grahani, Atisara & Abundant \\
\hline Bhringaraja & Eclipta alba L. Hassk. & Asteraceae & Sirah sula, Svasa & Common \\
\hline Punarnava & Boerhavia diffusa $\mathrm{L}$. & Nyctaginaceae & Sotha, Pandu & Rare \\
\hline Prapunnada & Cassia tora $\mathrm{L}$. & Fabaceae & Kustha, Kaphavatajanya Vikar & Common \\
\hline Atibala & Abutilon indicum L. Sweet & Malvaceae & Raktapitta, Vatarakta & Common \\
\hline Aparajita & Clitoria ternatea $\mathrm{L}$. & Fabaceae & Kustha, Mutraroga & Occasional \\
\hline Dudhi & Euphorbia hirta L. & Euphorbiaceae & Renal diseases & Common \\
\hline Arka & Calotropis procera (Aiton) Dryand. & Asclepiadaceae & Slesmodararoga, Pliharoga & Abundant \\
\hline Neeli- boot & Anagallis arvensis $\mathrm{L}$. & Primulaceae & Diuretic, Expectorant & Common \\
\hline Dhattura & Datura metel L. & Solanaceae & Krimi, Yuka, Liksa & Common \\
\hline Hathajori & Heliotropium indicum $\mathrm{L}$. & Boraginaceae & $\begin{array}{l}\text { In inflammation, } \\
\text { wound healing }\end{array}$ & Rare \\
\hline Pan Bel Laksmana & Ipomoea obscura L. Ker Gawl. & Convolvulaceae & In dysentery and ulcer & Occasional \\
\hline Raimuniya & Lantana camara $\mathrm{L}$. & Verbenaceae & For leprosy and scabies & Abundant \\
\hline Lunia & Portulaca oleracea L. & Portulacaceae & Anti- fungal, anti- rheumatic & Occasional \\
\hline Salsabuni & Trianthema portulacastrum $\mathrm{L}$. & Aizoaceae & Anti-inflammatory & Occasional \\
\hline Adhahpushpi & Portulaca oleracea L. Lehm. & Boraginaceae & In eye diseases & Rare \\
\hline
\end{tabular}

Literature search was carried out through the scientific engine Google Scholar (http://scholar.google.com), the databases ScienceDirect (http://www.sciencedirect.com), PubMed (http://www.ncbi.nlm.nih. gov/pubmed), Springer (http://www.springer.com), Scopus (http:// www.scopus.com), RSC (http://pubs.rsc.org/en/journals), SciFinder (http://www.libnet.ulg.ac.be/en/eresources/scifinder-scholar), and ACS (http://pubs.acs.org/). This review thoroughly investigates the ethnobotanical, phytochemical, and pharmacological studies reported on major weeds found in Gwalior and nearby regions.

\section{RESULTS AND DISCUSSION}

\subsection{Major Weeds in the Gwalior and Nearby Regions and their Medicinal Activities}

Oxalis corniculata $\mathrm{L}$. is a low growing creeping weed grows in tropical and temperate climate often found in gardens, wastelands, hedges, and roadsides. The plant contains tartaric acid, citric acid, malic acid, Vitamin C, and carotenes. It is incorporated in some ayurvedic formulations such as Changeri Ghrita and Amalaki Rasayan [10].

Bhringaraja is a common weed found throughout in India at damp places up to $1700 \mathrm{~m}$. It contains alkaloids ecliptine and nicotine and used as hair growth promoter and in Krimi-Roga and Sotha [11].
As per accepted classification, the Andrographis genus belongs to Acanthaceae family and includes 28 species of small shrubs of tropical Asian countries. Andrographis paniculata (Burm.f.) Nees is known as the "King of Bitters" because all plant parts are extremely bitter in taste. Flavonoids and diterpenoids are the major groups of secondary metabolites isolated from the plant. The plant possess various pharmacological effects such as antimicrobial, antifungal, antioxidant, anti-inflammatory, anthelmintic, antipyretic, anticancer, and antidiarrheal [12].

Punarnava or Rakta Punarnava consists of matured, dried plant (whole) of Boerhaavia diffusa L. (Family: Nyctaginaceae), found throughout in India and collected on maturity after rainy season. The herb is diffusely branched having stout rootstock, many long slender, prostrate, or ascending branches. Punarnavine is the chief alkaloidal constituent of plant. This plant is used as hepatoprotective, in the treatment of pandu roga and edema, and is an important ingredient of various ayurvedic formulations [13].

Cassia tora L. is a herbaceous annual belongs to the family Fabaceae and occurs as weed throughout the country in plains, ascending $1500 \mathrm{~m}$. in the Central Himalayas. The plant contains anthraquinones and fixed oil and therapeutically used in Ayurveda for the treatment of various ailments [14]. 
Cocculus hirsutus L. W. Theob. is known as Patalagarudi in Ayurveda. It is used in diseases of the urinary system. It is well-known herb used as first aid remedy in minor injuries. It alleviates kapha and vata doshas. It is used as deepanee, pachanee, and raktdoshagni and has special potency as a detoxifier. It is also an aphrodisiac and tonic [15].

Ashwagandha consists of dried mature roots of Withania somnifera L. Dunal., belonging to the family Solanaceae. It is found in wasteland, cultivated in field and open grounds throughout in India, and widely cultivated in certain areas of Madhya Pradesh and Rajasthan. It is a perennial shrub, contains alkaloids and withanolides, and is used as a potent adaptogen [16].

Abutilon indicum L. Sweet is found abundantly in temperate regions of India as a common weed on roadsides and other waste places in plains and hills throughout the year. Plant is traditionally used for a range of pharmacological and medicinal activities. Different parts of the plant contain specific phytoconstituents such as asparagine and hence possess different biological activities such as anti-inflammatory, analgesic, and antioxidant [17].

Clitoria ternatea L. is found in all tropical regions of the country, cultivated in gardens everywhere and often found along with hedges and thickets. The main phytoconstituents are tannins, starch, resins, taraxerol, and taraxerone. In Ayurveda, therapeutically it is used for sula, sotha and kustha roga [18].

Euphorbia is the largest genus of medicinal plants distributed through in India as well as in all tropical and subtropical regions as weed. Milky latex of the plant gives it the name "Dudhi." Chief constituents of the plant are quercetin, myricetin, and gallic acid. Plant possesses antiinflammatory, antidiabetic, antitumor, wound healing, antiallergic, analgesic, and antioxidant activities and was found effective in renal disorders [19].

Calotropis procera (Aiton) Dryand. found wild, more, or less throughout India. Herb contains glycoside calotropin and used in Ayurvedic formulations such as Mahavisagarbha Taila and Dhanvantara Ghrita. Pharmacologically, it was found active as analgesic, antitumor, antihelmintic, antioxidant, hepatoprotective, antidiarrheal, anticonvulsant, and antimicrobial [20].

Calotropis gigantea L. Dryand., known as Madar in Hindi, is a perennial herb with a long history for its mystical and traditional uses. It is a tall shrub growing throughout in India at dry wastelands. The herbs contain calotropin, $\alpha$-amyrin, $\beta$-amyrin, and glutathione which are the main constituents present in various plant parts and useful in diaphoretic, expectorant, leprosy, eczema, diarrhea, dysentery, cold, and cough and given as febrifuge [21].

Acalypha indica L. is a weed widely distributed throughout the plains of India. It has been reported to be useful in treating pneumoniae, asthma, rheumatism, and several other ailments. In Ayurveda, it is used as infusion of root, powder, decoction, cataplasm, succus (juice expressed), tincture, and liquid extract [22].

Achyranthes aspera L. is a common weed found throughout in India in approximately all waste and dry places because of nominal growth requirements. Saponin A, saponins B, oleanolic acid, amino acids, and hentriacontane are the main constituents of the plant. Whole plant ash is a good remedy for bleeding piles and abdominal problems [23].

Amaranthus viridis L. is possibly of Asian origin but now a cosmopolitan weed of tropics and subtropics of the world. This is an ascending, erect, annual, or shot perennial herb of about $1 \mathrm{~m}$ length

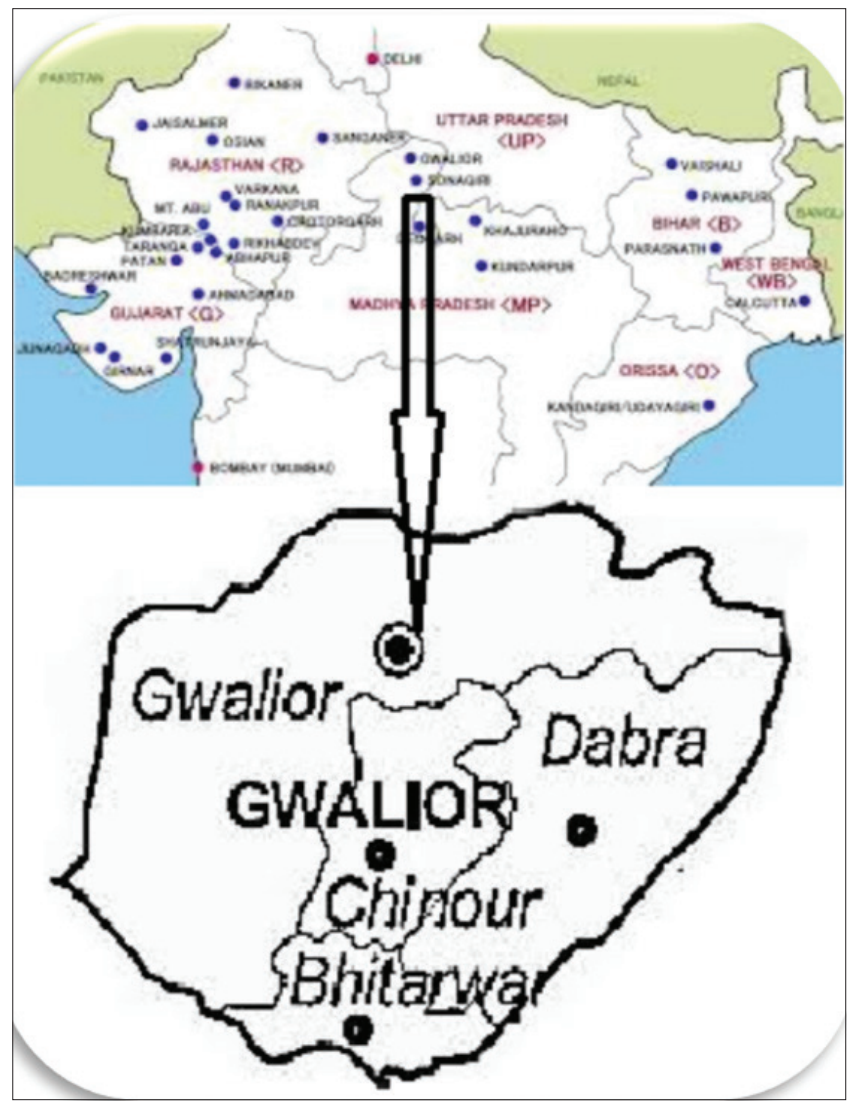

Figure 1: Gwalior and nearby regions.

and possesses analgesic and antipyretic properties. It is also used for the treatment of pain and fever in traditional systems of medicine [24].

Anagallis arvensis L. is a weed found throughout in India. It is known as Neeli Booti and poisonous in nature. This mucilaginous, acrid herb lowers the fever and has diuretic and expectorant effects. The drug is used internally for depression, tuberculosis, liver complaints, epilepsy, dropsy, and rheumatism. Extract is used to improve the complexion, especially for freckles externally [25].

Datura metel L. is a well-known devotionally important plant grew wild as weed and used as intoxicant and hallucinogen. The plant is rich in alkaloids, including atropine, scopolamine, and hyoscyamine, and contains flavonoids, phenols, tannins, saponins, amino acids, and sterols. Especially in India, it is used for the treatment of epilepsy, hysteria, heart diseases, cough, convulsions, diarrhea, skin diseases, etc. [26].

The genus Heliotropium comprises about 250 species and is distributed in tropical, subtropical, and warm temperate zones. It is very common throughout in India in sunny localities and on wastelands. The plant is very rich in pyrrolizidine alkaloids and essential oil and showed various biological activities such as antitumor, gastroprotective, antitubercular, anti-inflammatory, and wound healing activities [27].

Ipomoea obscura L. Ker Gawl. is a small climbing vine with cordate leaves and found effective in Ayurveda against dysentery, sores, and pustules [28].

Lantana camara L. is widespread in various habitats ranging from open region without shade, including wastelands, rainforest edges, beachfronts, and forests which due to wide ecological tolerances. 


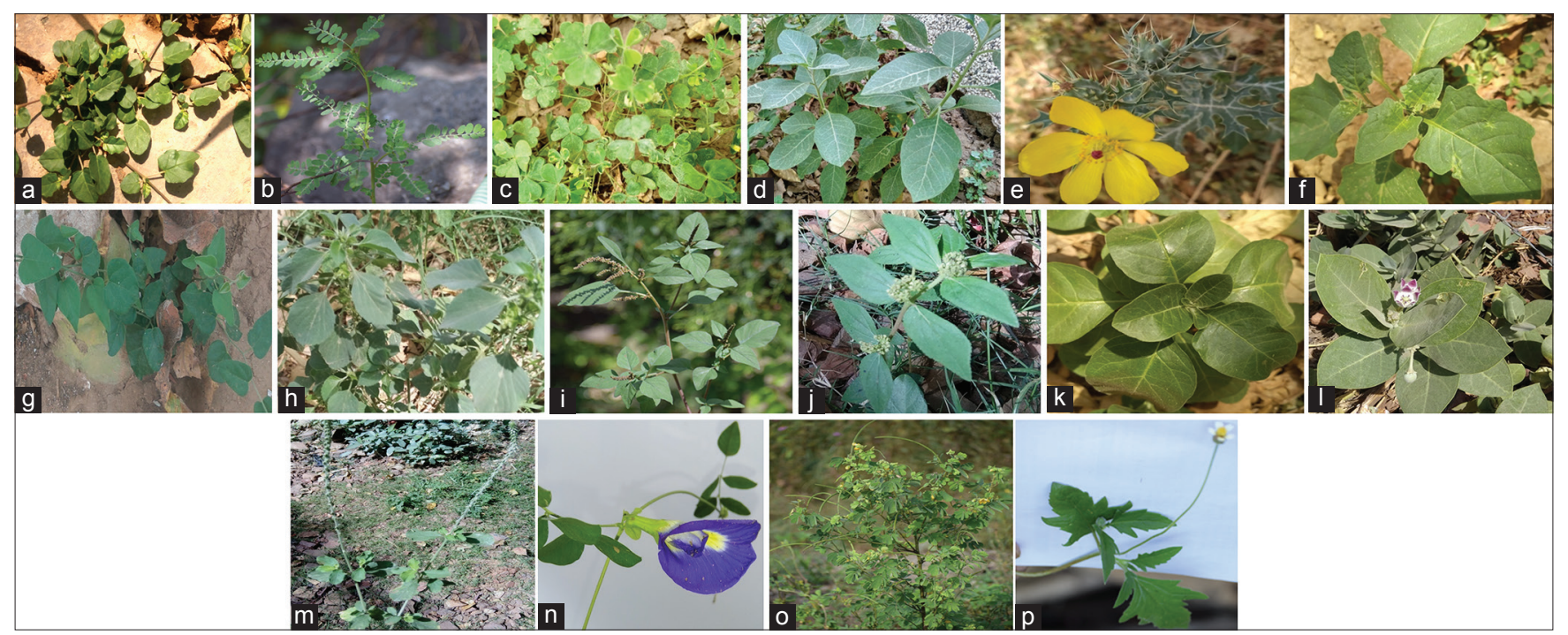

Figure 2: Photographs of few selected plants grow as the weed and used as medicine in Gwalior and nearby regions. (a) Boerhavia diffusa L., (b) Phyllanthus niruri L., (c) Oxalis corniculata L., (d) Withania somnifera L. Dunal., (e) Argemone Mexicana L., (f) Datura metel L., (g) Cocculus hirsutus L. W. Theob., (h) Acalypha indica L., (i) Amaranthus viridis L., (j) Euphorbia hirta L., (k) Calotropis procera (Aiton) Dryand., (l) Calotropis gigantea L. Dryand., (m) Achyranthes aspera L., (n) Clitoria ternatea L., (o) Cassia tora L., (p) Tridax procumbens (L.) L.

Therapeutically, it is used mainly as herbal medicine. The extract from the leaves showed antimicrobial, fungicidal, insecticidal, nematicidal, and biocidal activities. Its oil is used externally to treat leprosy and scabies, while plant extracts are used for the treatment of cancer, chicken pox, measles, asthma, ulcers, swellings, eczema, tumor, high blood pressure, bilious fevers, catarrhal infections, tetanus, and rheumatism and also to treat malaria [29].

Portulaca oleracea L. is an exotic invasive weed extensively distributed throughout the world. Inflorescence occurs any time in the year depending on the rainfall. Plant contains omega-3-fatty acids and linolenic acid, is traditionally used as antifungal and antirheumatic, and has been studied for antimicrobial, anti-inflammatory, antidiabetic, antioxidant, wound healing, analgesic, and diuretic properties [30].

Trianthema portulacastrum L. or salsabuni is widely distributed throughout in North India and other tropical and subtropical areas. It is widely distributed weed in several vegetable and grain crops. The plant has analgesic, antipyretic, anti-inflammatory, and stomachic properties and used in the treatment of asthma, bronchitis, jaundice, and edema. It is also used for throat troubles and as an antifungal agent. The leaves and stem are often taken as vegetable but could be toxic and can cause diarrhea. It is also used as fodder but may be poisonous to cattle [31].

Trichodesma indicum L. Lehm. is a perennial medicinal herb distributed in tropics and subtropics of Asia and found as a weed throughout in India, on roadsides and dry waste laces. In Ayurveda, the plant is used for diseases of eyes and also prescribed for the expulsion of the dead fetus. Whole aerial and subaerial parts are used to treat arthritis, dysentery, skin diseases, snake poisoning, and fever. Leaves and flowers are used as emollient and diuretic. The plant is useful in the conditions of vata and kapha and used to treat diarrhea, arthralgia, dyspepsia, inflammations, dysentery, leprosy, and some skin diseases [32].

Tridax procumbens (L.) L. is commonly known as "Ghamra." The plant is used in the Ayurvedic system of medicine for the treatment of various diseases and possesses various pharmacological activities such as immunomodulatory, antidiabetic, antihepatotoxic, antioxidant, anti-inflammatory, analgesic, and marked depression of respiration. The plant contains alkaloids, tannins, and flavonoids such as catechins and flavones and is rich in carotenoids and saponins [33].

The review supports a long history of the use of Phyllanthus niruri L. in the treatment of liver, kidney, and bladder problems, diabetes, and intestinal parasites. It is widely found throughout the tropical and subtropical countries of the world including India. In Indian traditional system of medicine, the plant is most commonly used in problems of the stomach and genitourinary tract including kidneys, liver, and spleen. The active phytoconstituents are flavonoids, alkaloids, terpenoids, lignans, polyphenols, tannins, coumarins, and saponins which are found in various parts [34].

Methanolic and ethanolic extracts of leaves and seeds of Argemone mexicana L. were tested for possible antimicrobial activity, where ethanolic extracts found more inhibitory against Gram-positive and negative bacteria [Figure 2] [35].

\section{CONCLUSION}

Climatic changes have significant direct and indirect effects on weed biology. The growth of weeds in cultivated medicinal crops is a problem to be treated with suitable herbicide, while, a number of weeds are of medicinal importance. The effect of climatic variations on weeds may vary by region, so a thorough understanding of physiological response of plant to such variations is needed to interpret the geographical distribution of weeds and species change.

This article may serve as the basis for further research to explore phytochemical modifications due to climatic changes in studied weeds and so to explore their systematic utilization accordingly in the treatment of prevalent diseases of the region under study.

Metabolomics studies in changing environment can explore more about existing flora and diverse therapeutic uses of above plants and could serve a basis to explore their importance in therapeutics. 


\section{ACKNOWLEDGMENT}

Sincere gratitude is being expressed to Prof. Vd. K. S. Dhiman (Director General, Central Council for Research in Ayurvedic Sciences [CCRAS], Ministry of Ayurveda, Yoga \& Naturopathy, Unani, Siddha and Homeopathy, Government of India) for his huge encouragement and support. The authors are also thankful to RARIDD, Gwalior, M.P. (an peripheral institute of CCRAS), for the library facilities.

\section{REFERENCES}

1. Zimdahl RL. Fundamentals of Weed Science. $3^{\text {rd }}$ ed. London: Academic Press: Elsevier; 2007. p. 17.

2. Gwalior Municipal Corporation. Available from: http://www. gwaliormunicipalcorporation.org/gwalior_geography.aspx. [Last accessed on 2018 Dec 06].

3. Richard W, Mark S, Caroline R, Brian M. The temperature dependence of enzyme rate enhancements. J Am Chem Soc 1999;121:7419-20.

4. Andrew C, Kevin G. Climate, energy and diversity. Proc R Soc B: Biol Sci 2006;273:2257-66.

5. Kristian P, Laura B, Bärbel G. Impact of climate change on weeds in agriculture: A review. Agron Sustain Dev 2014;34:707-21.

6. Peter K, Breitsameter L, Gerowitt B. Impact of climate change on weeds in agriculture: A review. Agron Sustain Dev 2014;34:707-21.

7. Aruna V, Prasad PV, Mithila J. Impact of climate change factors on weeds and herbicide efficacy. Adv Agron 2016;135:107-46.

8. Bruno LS, Angelie EE, Da Costa FB. Effect of the environment on the secondary metabolic profile of Tithonia diversifolia: A model for environmental metabolomics of plant. Sci Rep 2012;6:29265.

9. Naidu VS. Handbook on Weed Identification. Jabalpur, India: Directorate of Weed Science Research; 2012. p. 354.

10. The Ayurvedic Pharmacopoeia of India, Part-I. Vol. 3. New Delhi: Department of AYUSH, Ministry of Health and Family Welfare, Government of India; 2001. p. 36-8.

11. The Ayurvedic Pharmacopoeia of India, Part-I. Vol. 2. New Delhi: Department of AYUSH, Ministry of Health and Family Welfare, Government of India; 2001. p. 21-4.

12. Mol JS. Scientific aspects of the therapeutic use of Andrographis paniculata (kalmegh): A review. Int J Pharm Sci Rev Res 2014;27:10-6.

13. The Ayurvedic Pharmacopoeia of India, Part-I. Vol. 1. New Delhi: Department of AYUSH, Ministry of Health and Family Welfare, Government of India; 2001. p. 126-8.

14. The Ayurvedic Pharmacopoeia of India, Part-I. Vol. 3. New Delhi: Department of AYUSH, Ministry of Health and Family Welfare, Government of India; 2001. p. 154-5.

15. Marya BH, Bothara SB. Ethnopharmacological properties of Cocculus hirutus (L.) diels-a review. Int J Pharm Sci Rev Res 2011;7:108-12.

16. The Ayurvedic Pharmacopoeia of India, Part-I. Vol. 1. New Delhi: Department of AYUSH, Ministry of Health and Family Welfare, Government of India; 2001. p. 19-20.

17. The Ayurvedic Pharmacopoeia of India, Part-I. Vol. 1. New Delhi: Department of AYUSH, Ministry of Health and Family Welfare, Government of India; 2001. p. 25-6.
18. The Ayurvedic Pharmacopoeia of India, Part-I. Vol. 2. New Delhi: Department of AYUSH, Ministry of Health and Family Welfare, Government of India; 2001. p. 10-1.

19. Bin NM, Sadul HM, Mohammad A, Rabeya S, Sanjeeda S, Rabiul IB. Euphorbia hirta Linn. A wonderful miracle plant of Mediterranean region: A review. J Med Plants Stud 2017;5:170-5.

20. The Ayurvedic Pharmacopoeia of India, Part-I. Vol. 1. New Delhi: Department of AYUSH, Ministry of Health and Family Welfare, Government of India; 2001. p. 9-14.

21. Smita V, Dilip G, Mayank S. Calotropis gigantea: A review of its pharmacological activities. World J Pharm Pharm Sci 2016;5:1586-98.

22. Jagatheeswari D, Deepa J, Ali HS, Ranganathan P. Acalypha indica L -an important medicinal plant: A review of its traditional uses, and pharmacological properties. Int J Res Bot 2013;3:19-22.

23. The Ayurvedic Pharmacopoeia of India, Part-I. Vol. 2. New Delhi: Department of AYUSH, Ministry of Health and Family Welfare, Government of India; 2001. p. 7-9.

24. Reyad-ul FM, Shahjahan DM, Sharif T, Mohsina M. Present biological status of potential medicinal plant of Amaranthus viridis: A comprehensive review. Am J Clin Exp Med 2015;3:12-7.

25. Bakhsh G, Ahmad DA, Sabir H, Imran AM, Muhammad AU. Indigenous uses of medicinal plants in rural areas of Dera Ghazi Khan Punjab, Pakistan. ARPN J Agric Biol Sci 2012;7:750-62.

26. The Ayurvedic Pharmacopoeia of India, Part-I. Vol. 3. New Delhi: Department of AYUSH, Ministry of Health and Family Welfare, Government of India; 2001. p. 43-4.

27. Das GK, Abdullah MS. A review on Heliotropium indicum L. Int $\mathbf{J}$ Pharm Sci Res 2013;4:1253-8.

28. Arvind JM, Ravi A, Alka C, Prakash Z. Preliminary phytochemical screening of Ipomoea obscura (L)-a hepatoprotective medicinal plant. Int J PharmTech Res 2010;2:2307-12.

29. Neena P, Joshi PK. A review of Lantana camara studies in India. Int J Sci Res Publ 2013;3:1-11.

30. Chowdhary VC, Anusha M, Naresh K, Alumalai RK. A review on phytochemical and pharmacological profile of Portulaca oleracea Linn. (Purslane). Int J Res Ayurveda Pharm 2013;4:34-7.

31. Manpreet K, Aggarwal NK. Trianthema portulacastrum L.-the noxious weed and its control. Adv Plants Agric Res 2017;6:00213.

32. Kritika H, Vineet S, Devesh K, Kumar SN, Singh GD. Ethanopharmacology, pharmacology and phytochemistry of Trichodesma indicum (Linn.) R.Br. Indian J Agric Allied Sci 2015;1:141-50.

33. Ingle NA, Dubey HV, Navpreet K, Rahul G. Tridax procumbens: A multi useful weed a review. J Adv Oral Res 2014;5:14-6.

34. Kamruzzaman HM, Obydul H. A review on ethnomedicinal, phytochemical and pharmacological properties of Phyllanthus niruri. J Med Plants Stud 2016;4:173-80.

35. Gomare KS, Ghuget SR. Potential anti-microbial activity of Argemone mexicana solvent extracts against some pathogenic bacteria. Paripex Indian J Res 2012;1:1-2.

How to cite this article:

Kondalkar AS, Kondalkar A, Kumar VA, Mangal AK, Prakash O. Weeds

in Gwalior and nearby regions and their medicinal properties: A case study.

J App Biol Biotech. 2019;7(02):82-86. DOI: 10.7324/JABB.2019.70215 